Received: 27 November 2019

Accepted: 16 April 2020

Online: 18 April 2020

Authors:

M. S. Gawankar $ه$

College of Horticulture, Mulde Tal: Kudal,

Dist: Sindhudurg- 416520

D. C. Rajput, S.V. Juvekar, B. R. Salvi

College of Horticulture, Dapoli,

Ratnagiri 415712

$\bigotimes$ gawankarms@yahoo.co.in

Emer Life Sci Res (2020) 6(1): 16-20

E-ISSN: 2395-6658

P-ISSN: 2395-664X

DOI: https://doi.org/10.31783/elsr.2020.611620

\section{Research Article \\ Performance of nutmeg softwood grafts (Myristica fragrans Houtt.) at nursery stage in different growing media}

\author{
M. S. Gawankar, D. C. Rajput, S. V. Juvekar, B. R. Salvi
}

\begin{abstract}
Agro-climatic conditions of Konkan are suitable for the cultivation of fragrant nutmeg (Myristica fragrans Houtt). It is an important evergreen, aromatic tree that produces two distinctly different spices viz., nutmeg and mace. Nutmeg is the kernel of the fruit and mace is the waxy red colored dried aril that surrounded a single seed within a fruit. The initial growth of nutmeg grafts at nursery stage is very slow and it needs more duration for nurturing in the nursery. This phenomenon needs to be hastened for getting the good quality planting material in a short span of nursery stage. In view of this an experiment was laid to find out the effective growing media for obtaining vigorous nutmeg graft at College of Horticulture, Dapoli during the year 2018. The experiment was set in Randomized Block Design with six treatments and four replications. The media namely $\mathrm{T}_{1}$ : Soil + FYM + Sand (2:1:1) (Control), $\mathrm{T}_{2}$ : Soil+FYM+ Sand (2:1:1) with 1" cocopeat at top, $\mathrm{T}_{3}$ : Soil+Vermicompost + Sand $(2: 1: 1)$ with 1 " Cocopeat at top, $\mathrm{T}_{4}$ : Soil+FYM+Vermicompost+Sand $(1: 1: 1: 1)$ with 1 " Cocopeat at top, $\mathrm{T}_{5}$ : Soil+FYM+Vermicompost+Rice husk (1:1:1:1) with 1" Cocopeat at top, $\mathrm{T}_{6}$ : Soil+FYM+Vermicompost+Cocopeat $(1: 1: 1: 1)$ were tried.

Among various combinations of potting media, the treatment $T_{2}$ i.e. media containing Soil+FYM+Sand at 2:1:1 proportion exhibited the highest percentage of increment in height increment $(121.92 \%)$ while treatment $\mathrm{T}_{4}$ i.e. Soil+FYM+Vermicompost+Sand (1:1:1:1 proportion) with 1" Cocopeat at top showed maximum leaf length $(13.46 \mathrm{~cm})$ and maximum leaf area $(57.95 \mathrm{~cm} 2)$. Absolute growth rate (AGR) was highest in treatment $\mathrm{T}_{5}$ $(0.0646 \mathrm{~cm} /$ day $)$ while relative growth rate $(\mathrm{RGR})$ was greatest $(0.00101$ $\mathrm{cm} / \mathrm{cm} /$ day $)$ in treatment $\mathrm{T}_{6}$ (Soil $+\mathrm{FYM}+$ Vermicompost + Cocopeat $(1: 1: 1: 1)$.
\end{abstract}

Keywords absolute and relative growth rate, graft height, leaf area, media

\section{Introduction}

Nutmeg (Myristica fragrans Houtt.) is an important evergreen, aromatic tree that produces two different spices viz., nutmeg and mace. Nutmeg is the kernel of the fruit and mace is the waxy red colored dried aril portion that surrounds a single seed within the fruit [1]. India covers 22640 ha under nutmeg cultivation with a production of 14060 tonnes. Kerala is the leading state in area and production of nutmeg farming followed by Karnataka, Andaman and Nicobar [2]. Nutmeg is dioecious in nature; hence, asexual method of propagation is indispensable for the multiplication of the crop. Epicotyl grafting and softwood grafting have been standardized by Dr. Balasaheb Sawant Konkan Krishi Vidyapeeeth, Dapoli. 
However, softwood grafting is the commercially followed method as the epicotyl grafting method cannot be followed after rainy season (June-September) due to the low success rate under high temperature conditions. Though softwood grafting is employed in Konkan region, the initial growth of nutmeg grafts is very slow in the nursery as well as under field conditions. This growth is required to get better quality planting material, better price and precocity in fruiting.

Potting mixture plays an important role in the growth of any horticultural crop at nursery stage. It helps to produce the quality planting material on large scale and fetch a good price. Soil, sand, vermicompost, cocopeat, rice husk etc., are various media which could be used as a potting mixture. Very limited work has been done regarding the use of media for hastening the growth of nutmeg grafts. In this context, an experiment was carried out to test the performance of softwood grafts of nutmeg (Myristica fragrans Houtt.) in different growing media at nursery stage during the year 2018.

\section{Methodology}

The experiment was conducted at College of Horticulture, Dapoli under Dr. Balasaheb Sawant Konkon Krishi Vidyapeeth, Dapoli, Dist. Ratnagiri 415712 (MS.) during the year 2018. The experiment was laid out in Randomized Block Design with four replications and six treatment namely $\mathrm{T}_{1}$ : Soil $+\mathrm{FYM}+$ Sand (2:1:1) (Control), $\mathrm{T}_{2}$ : Soil $+\mathrm{FYM}+$ Sand (2:1:1) with 1" cocopeat at top, $\mathrm{T}_{3}:$ Soil + Vermicompost + Sand (2:1:1) with 1" Cocopeat at top, $\mathrm{T}_{4}$ : Soil $+\mathrm{FYM}+$ Vermicompost + Sand $(1: 1: 1: 1)$ with 1" Cocopeat at top, $\mathrm{T}_{5}$ : Soil + FYM + Vermicompost + Rice husk (1:1:1:1) with 1" Cocopeat at top, $\mathrm{T}_{6}$ : Soil + FYM+ Vermicompost + Cocopeat $(1: 1: 1: 1)$. Three months old soft wood grafts of nutmeg grown in 6 " $\times 8$ " size polybags were used for the experimental purpose. Such grafts were transferred in 9"x11" size polythene bags having different media combination of soil, FYM, vermicompost, sand, coco-peat and rice husk as per the treatment. A unit of 50 grafts was used per replication.

Average leaf length $(\mathrm{cm})$, average leaf width $(\mathrm{cm})$ and leaf area $\left(\mathrm{cm}^{2}\right)$ were measured with the help of a portable leaf area meter (Licor, company. USA.). Growth rate and per cent increment in height were measured as per the following methods.

\section{Absolute growth rate (cm/day) AGR}

Absolute growth rate (cm/day) AGR for the increase in the plant height was calculated by using a formula given by Radford [3] and was expressed as the height in $\mathrm{cm} /$ day.

$$
\operatorname{AGR}=\frac{\left(\mathrm{H}_{2}-\mathrm{H}_{1}\right)}{\left(\mathrm{t}_{2}-\mathrm{t}_{1}\right)}
$$

Where, $\mathrm{H}_{2}$ and $\mathrm{H}_{1}$ represent height per plant and $\mathrm{t}_{2}$ and $\mathrm{t}_{1}$ time intervals between two observations, respectively.

\section{Relative growth rate $(\mathrm{cm} / \mathrm{cm} /$ day $)$}

It is the rate of increase in height $(\mathrm{cm})$ per duration and expressed as $\mathrm{cm} / \mathrm{cm} /$ day. RGR was calculated by the using formula given by Briggs et al., [4].

$$
\text { RGR }=\frac{\left(\log _{e} \mathrm{H}_{2}-\log _{\mathrm{e}} \mathrm{H}_{1}\right)}{\left(\mathrm{t}_{2}-\mathrm{t}_{1}\right)}
$$

Where, $\mathrm{H}_{2}$ and $\mathrm{H}_{1}$ represent height per plant and $\mathrm{t}_{2}$ and $\mathrm{t}_{1}$ times, respectively.

\section{Per cent increase in height $(\%)$}

The per cent increase in height was calculated by using following formula: 


$$
\text { Percent increse in height }(\%)=\frac{\text { Final height of graft }(\mathrm{cm})-\text { Initial height of graft }(\mathrm{cm})}{\text { Initial height of graft }(\mathrm{cm})} \times 100
$$

Statistical analysis of the data was performed by following the standard method of analysis of variance described by Panse and Sukhatme [5]. The standard error of mean (S.E. \pm ) was worked out and the critical difference at 5 per cent level of significance was calculated wherever the results were found significant.

\section{Results and Discussion}

The data recorded during the period of investigation are presented in Table 1 and graphically illustrated with Figure 1.

\section{Effect of growing media on height increment}

The data presented in Table 1 revealed that the media having Soil + FYM + Vermicompost + Rice husk with 1" Cocopeat layer at top $\left(\mathrm{T}_{5}\right)$ recorded significantly maximum graft height $(41.89 \mathrm{~cm})$ followed by the treatment $\mathrm{T}_{1}(41.63 \mathrm{~cm}), \mathrm{T}_{2}(40.59 \mathrm{~cm})$ and $\mathrm{T}_{6}(38.36 \mathrm{~cm})$ and were at par with each other. Nevertheless, treatment $T_{2}$ i.e. media containing Soil + FYM + Sand in 2:1:1proportion showed highest percentage of height increment $(121.92 \%)$. Purwantoro [6] suggested that rice husk is a natural silica fertilizer containing high organic matter and silica. The increases in height in these treatments might be due to the presence of FYM which was the one of the components of the media. The findings of Chaudhary [7] support our study results who reported that FYM is a main source of organic matter for the supply of essential nutrients for the plant growth. Similar finding were reported by Gawankar [8] in jackfruit with media containing Soil + Vermicompost + Rice husk (2:1:1) media.

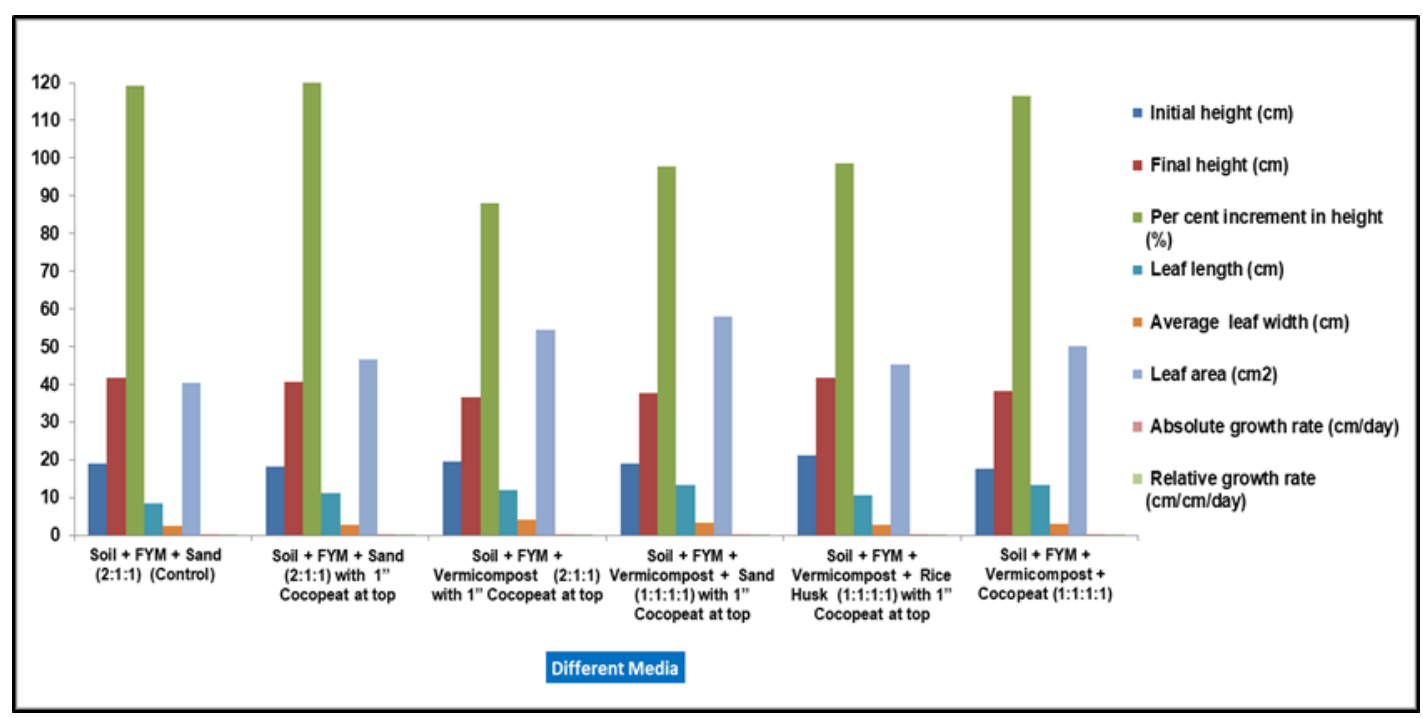

Figure 1. Different growth parameters as influenced by growing media

\section{Effect of growing media on leaf length}

The leaf length was maximum in treatment $\mathrm{T}_{4}(13.46 \mathrm{~cm})$ i.e. Soil + FYM + Vermicompost + Sand 1:1:1:1 with 1" Cocopeat at top which was at par with $\mathrm{T}_{6}(13.27 \mathrm{~cm}), \mathrm{T}_{3}(12.01 \mathrm{~cm}), \mathrm{T}_{2}(11.05 \mathrm{~cm})$ and $\mathrm{T}_{5}(10.63$ $\mathrm{cm})$. The minimum length of leaf was noticed in treatment $T_{1}(8.33 \mathrm{~cm})$ i.e. Soil $+F Y M+S a n d ~ 2: 1: 1$ with 1 "Cocopeat at top. The study results revealed that leaf length of nutmeg grafts was influenced by media treatments. It was maximum in $\mathrm{T}_{4}$ treatment with Soil $+\mathrm{FYM}+$ Vermicompost + Sand 1:1:1:1 with 1" Cocopeat at top and minimum in $\mathrm{T}_{1}$ treatment i.e. Soil $+\mathrm{FYM}+$ Sand 2:1:1 Control. This could be attributed to the inclusion of vermicompost in the media. 


\section{Effect of growing media on average leaf width}

The average leaf width was also influenced by different types of media and treatment $\mathrm{T}_{3}$ with Soil + Vermicompost + Sand at 2:1:1 proportion with 1" Cocopeat at top recorded maximum width $(4.15 \mathrm{~cm})$ and it was at par with $\mathrm{T}_{4}(3.31 \mathrm{~cm})$. The minimum average leaf width was found in $\mathrm{T}_{1}(2.59 \mathrm{~cm})$ i.e. Soil $+\mathrm{FYM}$ + Sand in 2:1:1 ratio which was at par with treatment $\mathrm{T}_{5}(2.78 \mathrm{~cm}), \mathrm{T} 2(2.83 \mathrm{~cm})$ and $\mathrm{T}_{6}(3.14 \mathrm{~cm})$. Similar results were reported by Gawankar [8] in jackfruit with Soil + FYM (3:1) media.

\section{Effect of growing media on leaf area}

The maximum leaf area was recorded in treatment $\mathrm{T}_{4}\left(57.95 \mathrm{~cm}^{2}\right)$ i.e. Soil $+\mathrm{FYM}+$ Vermicompost + Sand in 1:1:1:1 ratio with 1 " Cocopeat at top which was at par with $\mathrm{T}_{3}\left(54.46 \mathrm{~cm}^{2}\right)$ and $\mathrm{T}_{6}\left(50.09 \mathrm{~cm}^{2}\right)$. The minimum leaf area was found in treatment $\mathrm{T}_{1}\left(40.38 \mathrm{~cm}^{2}\right)$ i.e. Soil $+\mathrm{FYM}+$ Sand in 2:1:1 proportion (Control) and was at par with treatment $\mathrm{T}_{5}\left(45.17 \mathrm{~cm}^{2}\right)$ and $\mathrm{T}_{6}\left(46.51 \mathrm{~cm}^{2}\right)$. Among the various treatments of growing media treatment $\mathrm{T}_{4}$ (Soil + FYM + Vermicompost + Sand 1:1:1:1 with 1" Cocopeat at top produce the maximum leaf area. This could be due to production of more number of functional leaves and absorption of nutrient through media.

Table 1. Growth characters as influenced by different growing media

\begin{tabular}{|c|c|c|c|c|c|c|c|c|c|}
\hline & Treatments & $\begin{array}{l}\text { Initial } \\
\text { height }(\mathrm{cm})\end{array}$ & $\begin{array}{l}\text { Final } \\
\text { height }(\mathrm{cm})\end{array}$ & $\begin{array}{l}\text { Per cent } \\
\text { increment in } \\
\text { height }(\%)\end{array}$ & $\begin{array}{l}\text { Leaf length } \\
(\mathrm{cm})\end{array}$ & $\begin{array}{l}\text { Average } \\
\text { leaf width } \\
\text { (cm) }\end{array}$ & $\begin{array}{l}\text { Leaf area } \\
(\mathrm{cm} 2)\end{array}$ & $\begin{array}{l}\text { Absolute } \\
\text { growth rate } \\
\text { (cm/day) }\end{array}$ & $\begin{array}{l}\text { Relative growth } \\
\text { rate } \\
(\mathrm{cm} / \mathrm{cm} / \text { day })\end{array}$ \\
\hline $\mathbf{T}_{1}$ & $\begin{array}{c}\text { Soil + FYM + } \\
\text { Sand (2:1:1) } \\
\text { (Control) } \\
\end{array}$ & 19.00 & 41.63 & 119.10 & 8.33 & 2.59 & 40.38 & 0.0600 & 0.00100 \\
\hline $\mathbf{T}_{2}$ & $\begin{array}{c}\text { Soil + FYM + } \\
\text { Sand }(2: 1: 1) \\
\text { with 1" } \\
\text { Cocopeat at top }\end{array}$ & 18.29 & 40.59 & 121.92 & 11.05 & 2.83 & 46.51 & 0.0612 & 0.00100 \\
\hline $\mathbf{T}_{3}$ & $\begin{array}{c}\text { Soil + FYM + } \\
\text { Vermicompost } \\
(2: 1: 1) \text { with 1" } \\
\text { Cocopeat at top }\end{array}$ & 19.53 & 36.74 & 88.12 & 12.01 & 4.15 & 54.46 & 0.0558 & 0.00082 \\
\hline $\mathbf{T}_{4}$ & $\begin{array}{c}\text { Soil + FYM + } \\
\text { Vermicompost } \\
\text { + Sand(1:1:1:1) } \\
\text { with 1" } \\
\text { Cocopeat at top }\end{array}$ & 19.10 & 37.78 & 97.80 & 13.46 & 3.31 & 57.95 & 0.0606 & 0.00085 \\
\hline $\mathbf{T}_{5}$ & $\begin{array}{c}\text { Soil + FYM + } \\
\text { Vermicompost } \\
\text { + Rice Husk } \\
(1: 1: 1: 1) \text { With } \\
\text { 1" } \\
\text { Cocopeat at top }\end{array}$ & 21.10 & 41.89 & 98.53 & 10.63 & 2.78 & 45.17 & 0.0646 & 0.00088 \\
\hline$T_{6}$ & $\begin{array}{c}\text { Soil + FYM + } \\
\text { Vermicompost } \\
\text { + Cocopeat } \\
(1: 1: 1: 1) \\
\end{array}$ & 17.71 & 38.36 & 116.60 & 13.27 & 3.14 & 50.09 & 0.0637 & 0.00101 \\
\hline \multicolumn{2}{|c|}{ S. Em \pm} & 0.67 & 1.26 & & 1.10 & 0.32 & 3.76 & & \\
\hline \multicolumn{2}{|c|}{ CD@ @ } & 2.02 & 3.81 & & 3.33 & 0.98 & 11.35 & & \\
\hline
\end{tabular}

The dimensions of leaf namely leaf length, width and leaf area reveals the capacity of plant to capture solar radiation which is the main determinant of photosynthesis and overall growth of the graft. The greater number of leaves increases the metabolic activity of cell which results in healthy and vigorous growth of grafts. In addition, more number of leaves, in turn give rise to more photosynthesis which might have increased the leaf area at greater extent [9]. Similar findings were reported by Qayom [10] who used Soil + Sand + compost + coir pith (2:1:1:1) in mango, Bhardwaj [11] who used Vermicompost + Sand + pond Soil (1:1:1) with $2 \mathrm{~cm}$ Cocopeat in Papaya, Gawankar [8] who used Soil + FYM (3:1) as a media in jackfruit. 


\section{Effect of growing media on Average growth rate (AGR)}

The study revealed that treatment T5 recorded maximum AGR. According to Radford [3] AGR is the actual increase in the size of an individual plant per unit time under a given condition. In present study, the physiological changes observed in the plant grown in the media having vermicompost and rice husk could be attributed to the humic substances and the micro elements like $\mathrm{Zn}$ provided by the vermicompost and to the properties of rice husk as a fertilizer. Similar findings were reported by Ramteke et al., [12] in papaya and Gawankar [8] in jackfruit.

\section{Effect of growing media on Relative growth rate (RGR)}

RGR is an index of efficiency of the plant to grow in the context of the photosynthesis of the crop per unit area. It shows the efficiency of a plant to grow on per unit area per unit time. It is the growth rate relative to its previous size and is also called as the exponential growth rate which is the quantification of the speed of the plant growth.In the present study, maximum RGR $(0.00101 \mathrm{~cm} / \mathrm{cm} /$ day $)$ was observed in treatment $\mathrm{T}_{6}$ i.e. Soil + FYM + Vermicompost + Cocopeat in 1:1:1:1 proportion. The minimum RGR (0.00082 $\mathrm{cm} / \mathrm{cm} /$ day) was recorded in treatment $\mathrm{T}_{3}$ i.e. Soil $+\mathrm{FYM}+$ Vermicompost (2:1:1) with 1" Cocopeat at top. Similar findings were reported by Ramteke et al. [12] in papaya and Gawankar [8] in jackfruit.

\section{Conclusion}

The study results revealed that different components of growing media play an important role in the growth and vigor of the nutmeg graft. The usage of vermicompost, rice husk and cocopeat in the present investigation was successful and it might be due to the changes in the physical and chemical properties of the soil like bulk density, $\mathrm{pH}$, soil moisture content, electrical conductivity, organic carbon and nutrient supply which are favorable for the graft growth.

\section{References}

[1] A. L., Dawidowicz and M. P. Dybowski (2012). Determination of myristicin in commonly spices applying SPE/GC. Food chem. Toxical., 50: 2362-2367.

[2]. www.spicesboard.com

[3] P. J. Radford (1967). Growth analysis formulae-their use and abuse. Crop Sci., 7: 171-175.

[4] G. E. Briggs, F. Kidd and C. West (1920). A quantitative analysis of plant growth: Part II. Ann. Appl .Biol., 7: 202-203.

[5] V. G. Panse and P. V. Sukhatme (1985). Statistical method for agricultural workers. ICAR pub.

[6] R. S. Purwantoro (2016). Effect of media on seed germination and seedling growth of Aganope heptaphylla (Leguminosae). Nusantara Biosci., 8:150-154

[7] Chaudhary, M. I. (1996). Soil and Fretilizer. Horticulture, 259-260.

[8] M. S. Gawankar (2019). Studies on seed storage methods for seed viability and effect of growing media on softwood grafting in jackfruit (Atrocarpus heterophyllus Lam.) A Ph.D. (Agri.) thesis submitted to Dr. B. S. Konkan Krishi Vidyapeeth, Dapoli.

[9] R. Sridhar (2014). Effect of season on the success and growth of Mango (Mangifera indica L.) softwood grafts under southern transitional zone of Karnataka. Environment and Ecology, 32: 1717-1719.

[10] A. Qayom (2011). Studies on the effect of media composition on Seed germination, growth and its effect on grafting in mango (Mangifera Indica L.). M.Sc. (Horti.) Thesis submitted to University of Agricultural Sciences, Bangalore.

[11] R. L. Bhardwaj (2014). Effect of growing media on seed germination and seedling growth of Papaya Cv. 'Red Lady'. Afr. J. Plant Sci., 8: 178-184.

[12] V. Ramteke, D. H. Paithankar, E. P. Ningot and V. K. Kurry (2015). Effect of GA3 and propogation media on germination, growth and vigour of papaya Cv. Coorg honey dew. Int. Quarterly J. Life Sci., 10:1011-1016. 